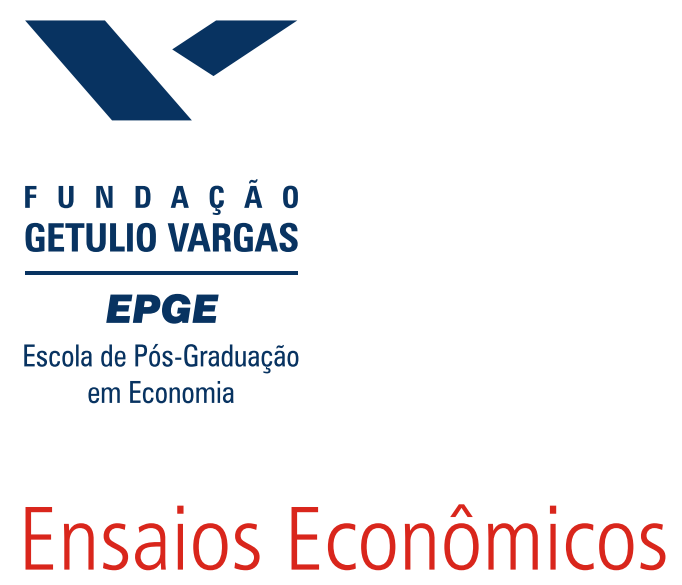

$$
\begin{aligned}
& \text { Escola de } \\
& \text { Pós Graduação } \\
& \text { em Economia } \\
& \text { da Fundação } \\
& \text { Getulio Vargas }
\end{aligned}
$$

$N^{\circ} 618$

ISSN 0104-8910

Foreign direct investment spillovers in Portugal: additional lessons from a country study

Renato Galvão Flôres Junior, Maria Paula Fontoura, Rogério Guerra Santos 
Os artigos publicados são de inteira responsabilidade de seus autores. As opiniões neles emitidas não exprimem, necessariamente, o ponto de vista da Fundação Getulio Vargas. 


\section{Foreign direct investment spillovers in Portugal: additional lessons from a country study +}

Renato G. Flôres Jr.*, Maria Paula Fontoura** and Rogério Guerra Santos***

* EPGE / Fundação Getúlio Vargas, Praia de Botafogo 190, Rio de Janeiro 22253-900, Brazil (corresponding author; e-mail rfatwto@yahoo.com)

** ISEG / Universidade Técnica de Lisboa, Lisbon

*** Instituto Superior de Gestão, Lisbon

+ The authors are indebted to participants in the $3^{\text {rd }}$ International Workshop on European Economy, ISEG/Lisbon and the Irish Economic Association Fourteenth Annual Conference (Waterford). Comments and suggestions from Frank Barry, German Calfat, Rod Falvey, Isabel Proença and Frances Ruane are heartfully acknowledged. 


\title{
Foreign direct investment spillovers in Portugal: additional lessons from a country study
}

\begin{abstract}
This paper investigates the impact of FDI on the productivity of Portuguese manufacturing sectors. Model specification is improved by considering the choice of the most appropriate interval of the technological gap for spillovers diffusion. We also allow for sectoral variation in the coefficients of the spillover effect; idiosyncratic sectoral factors are identified by means of a fixed effects model. Inter-sectoral positive spillover effects are examined. Significant spillovers require a proper technological differential between foreign and domestic producers and favourable sectoral characteristics. They may occur in modern industries in which the foreign firms have a clear, but not too sharp, edge on the domestic ones. Agglomeration effects are also one pertinent specific influence.
\end{abstract}

JEL Codes: F21, F23, O19, O52

Keywords: agglomeration effect; domestic productivity; foreign direct investment; Portugal, productivity spillovers, technology gap.. 


\section{INTRODUCTION}

Historically, foreign direct investment (FDI) meant capital inflows and additional employment. In a world of financial crises, volatile credibility and footloose industrial plants, what does FDI mean? One major indirect benefit, much cited in the literature on the gains from FDI, is the increase in domestic firms' productivity. This is related to the concept of technology or productivity spillovers, which embodies the fact that foreign enterprises own intangible assets such as technological know-how, marketing and managerial skills, international experience or reputation, which can be transmitted to domestic firms, raising their productivity level. Once a multinational has set up a subsidiary, some of these advantages may not be totally internalised and thus spill over to domestic firms.

Although theory has identified a wide range of possible FDI spillover's channels - they may occur through demonstration/imitation effects, the labour market (via skill enhancement), export activities, increased competitive pressure (spurring local firms to operate more efficiently) and backward or forward linkages between local and foreign firms -, empirical evidence on their diffusion is ambiguous. Robust empirical support for positive spillovers is hard to find, as shown for instance, in the surveys by Görg and Greenaway (2004) and Crespo and Fontoura (2006a and 2006b).

Heterogeneity on the spillover effect has been associated to ambiguity in the sign of the effect in the case of some spillover channels. The main negative effect identified in the literature is related to the increased competition induced by multinational entreprises (MNEs) on domestic firms. On one hand, it is an incentive for the latter to make a more efficient use of existing resources and technology or even to adopt new technologies. On the other hand, the presence of MNEs may imply 
significant losses in (domestic) market shares, driving operation to a less efficient scale, with a consequent increase in average costs, as shown by Aitken and Harrisson (1999). Skill enhancement, resulting from learning by doing among domestic firms, and on-thejob training of domestic employees may also have a negative effect as MNEs may attract the best workers from domestic firms by offering higher wages, Sinani and Meyer (2004).

Another possible negative impact has been related to forward linkages, considering that production quality upgrade induced by the presence of MNEs may lead to an increase in prices which penalises domestic firm's costs, Javorcik (2004). Ambiguity as regards the channel's effect is reinforced by the fact that it may be difficult to distinguish one channel from another, as they are often interdependent, Kinoshita (2001).

Recent literature stresses that the existence, sign and magnitude of spillovers appear to depend on idiosyncrasies of the recipient countries, sectors and firms, as well as of foreign investment. However, empirical evidence does not allow definite conclusions for the majority of the possible determinant factors, as it is basically inconsistent or still insufficient to produce unequivocal conclusions, Crespo and Fontoura (2006a). The most robust empirical result relates to the absorptive capacity of domestic firms, which Narula and Marin (2003) have defined as "the ability to internalise knowledge created by others and modifying it to fit their own specific applications, processes and routines" (op. cit, p.23). With regard to this factor, it is maintained that some technological gap between foreign and domestic firms must exist for spillovers to occur.

Most studies that have evaluated the existence of FDI externalities are circumscribed to intra-sectoral externalities. Only very recently some research on inter- 
sectoral externalities has emerged ${ }^{1}$. The main reason for the scarce attention devoted to the latter is related to the difficulty on their measurement. Some authors have argued, nonetheless, that between-industries externalities are more probable than within industries ones, based on the fact that the possible negative effect associated to the competitiveness channel is more evident at the intra-sectoral level; and also because efficiency gains are easier to obtain in backward-forward relations, due to a greater incentive to co-operation, Kugler (2001).

This paper investigates the impact of foreign investment on the productivity performance of Portuguese firms, both at the intra and inter-sectoral levels during the nineties, more precisely in the period 1992-95. Portugal, at that time, became an important recipient of FDI inflows after having joined the European Union (EU) in $1986^{2}$. FDI as a percentage of GDP rose from less than 1 per cent, before 1986, to 5 per cent in 1990 and, although this ratio decreased between 1991 and 1994, another positive trend was to be noted in the second half of the nineties, reaching a peak of 11.4 per cent in 1998.

A significant share of FDI inflows to the Portuguese economy has been increasingly directed to the manufacturing sector (47.4 per cent of total inflow in 199599). It should, however, be pointed out that, if foreign direct divestment is taken into account, the previous picture is altered to more modest values since the beginning of the 1990s. In fact, for this decade, inward FDI net of divestment amounts to an average of only 2 per cent of GDP, while the 1998 peak is reduced to 2.54 per cent.

All this obviously raises interest on the effects of FDI in Portugal, as Santos (1991), Farinha and Mata (1996) and Proença et al (2006) testify, and similar

\footnotetext{
${ }^{1}$ It is the case of Barrios and Strobl (2002), Schoors and van der Tol (2002), Damijan et al. (2003), Yudaeva et al. (2003) and Kugler (2005).

${ }^{2}$ For a clear and well-documented survey of the preparations for joining the EU and the post-1986 period see chapters 5 and 6 in Mateus (1998).
} 
developments in the Irish economy raised identical interests (see, among many, Görg and Ruane (1998)).

Our study is conducted for manufactures, at the sectoral level. The panel nature of the data allows bypassing somehow the relatively small sample size, going beyond a pooled analysis and using techniques particularly appropriate to exploit sector specificities.

With regard to intra-sectoral externalities, we explicitly include in the model the technological gap between foreign and domestic firms, given that, since Findlay's (1978) pioneering contribution - reinforced by Borensztein et al. (1998) - it proves to be a fundamental precondition to enable FDI spillovers' diffusion. Indeed, it is surprising that, in spite of these contributions, most previous empirical studies have overlooked such condition. Moreover, we innovate and, as in Flôres et al. (2002), we improve model specification by searching the most appropriate interval on what concerns the influence of the technological gap on spillovers diffusion. Sectoral variation in the parameters of the spillovers effect and the identification of specific (idiosyncratic) sectoral factors were also tested.

Finally, we tried to uncover, in an exploratory way, inter-sectoral positive spillover effects. This led us to raise the possibility that geographic factors, notably agglomeration effects, may play an important role in spillovers diffusion, as suggested by Audretsch and Feldman (1996) and Audretsch (1998). Something related to the fact that spillover channels are reinforced at the regional level, Girma and Wakelin (2001), Girma (2003), Torlak (2004) and Jordan (2005).

Overall, our conclusions reinforce points in Lall and Narula (2004), who make a strong pledge for a systems view of the spillovers phenomenon. Location, or rather 
'basic location advantages' are definitely one component of such more encompassing view

The following section presents the data set and the basic model. We then investigate the best range for the technological gap and, after, a varying spillover coefficient, according to the industry groups, is used. This approach is continued with the testing of a fixed-effects model. Another section exploits the panel data structure of the residuals to draw an exploratory picture of inter-sectoral spillovers. Incorporation of the spatial dimension naturally leads to consider agglomerative effects. A final section concludes.

\section{DATA AND BASIC MODELS}

\section{Preliminary data analysis}

Our sample comprises 36 observations related to nine manufacturing sectors, for the period from 1992 to 1995. The data come from the Inquérito às Empresas Harmonizado, conducted annually by the Instituto Nacional de Estatística - INE $^{3}$. This survey investigates all manufacturing firms with 100 or more employees, which are believed to represent at least 80 per cent of total employment and of value added by manufactures.

The sectors correspond to the two-digit level of the standard industrial classification; they are labelled from 31 to 39 and their description is in the Appendix.

Seven variables were computed at the yearsxsectors level:

PROD (productivity of the domestic firms; in million escudos per worker) - total value added divided by the number of workers;

\footnotetext{
${ }^{3}$ The Inquérito às Empresas Harmonizado is of the responsibility of the Serviço de Estatísticas Estruturais das Empresas, Departamento de Estatísticas das Empresas/INE.
} 
FP (foreign presence) - the ratio of value added by all foreign firms to total value added;

SL (skilled labour) - the ratio of white collar to blue collar employees;

CI (capitalistic intensity, in million escudos per worker) - total fixed assets divided by the number of workers;

$\mathrm{H}$ (a concentration index) - the ratio of the total number of employees in firms with 500 or more employees to total employment in the sector;

SE (scale economies) - the ratio of the average output of domestic entreprises to the average output of firms with 500 or more employees;

DP (domestic performance) - the ratio of domestic firms' productivity to the productivity of foreign enterprises.

Variable DP is a key element in our analysis. It is related to the technological gap between the domestic and foreign producers; the lower its values the higher the gap. An alternative specification would be to define a variable equal to 1-DP , which would directly portray the gap.

Table 1 shows the basic statistics for the seven variables; most roughly follow the pattern of another key variable, PROD, with a positive asymmetry indicating that the maximum can be much larger than the mean, though all coefficients of variation are lower than 0.68 (with the exception of $\mathrm{H}$ ). A slight negative asymmetry is present only for SE. Some extreme values can be quite wild, as in the case of $\mathrm{H}$ and DP. The maximum performance of 2.88 , for the gap, shows that domestic firms can be more productive than the foreign ones; what is indeed true for sectors 37 and 39. The former is basic metallurgy (see the Appendix), predominantly Portuguese, while the latter is a more heterogenous bunch of firms where it is difficult to identify a definite foreign skill. 
The above information is complemented by Table 2, giving the year averages, by sector, for each variable. Sectoral variations are quite large, for all variables ${ }^{4}$.

TABLE 1

DESCRIPTIVE STATISTICS FOR THE SEVEN VARIABLES

\begin{tabular}{cccccc} 
& Mean & Stand. dev. & Asymmetry & Min & Max \\
\hline PROD & 3.49 & 1.77 & 1.36 & 1.26 & 9.25 \\
FP (x 100) & 21.17 & 13.21 & 1.34 & 2.67 & 57.14 \\
SL & 3.24 & 1.79 & 0.87 & 1.09 & 7.26 \\
CI & 16.97 & 11.37 & 0.66 & 3.24 & 39.81 \\
H & 0.15 & 0.15 & 2.41 & $0.00^{*}$ & 0.77 \\
SE & 0.17 & 0.08 & -0.23 & 0.04 & 0.30 \\
DP & 0.88 & 0.50 & 2.68 & 0.39 & 2.88
\end{tabular}

* In sector 39 there were no firms with 500 or more employees.

TABLE 2

SECTOR AVERAGES

\begin{tabular}{cccccccccc} 
& 31 & 32 & 33 & 34 & 35 & 36 & 37 & 38 & 39 \\
\hline PROD & 5.1 & 1.6 & 2.5 & 4.7 & 6.9 & 3.3 & 2.9 & 2.4 & 2.1 \\
FP & 23.8 & 19.1 & 8.0 & 16.5 & 20.3 & 22.1 & 6.4 & 52.5 & 21.8 \\
SL & 1.7 & 7.1 & 3.6 & 1.3 & 1.2 & 4.3 & 2.9 & 2.9 & 4.2 \\
CI & 15.1 & 5.4 & 10.0 & 32.3 & 34.2 & 18.0 & 24.6 & 9.6 & 3.5 \\
H & 0.10 & 0.09 & 0.03 & 0.17 & 0.11 & 0.11 & 0.48 & 0.24 & 0.00 \\
SE & 0.19 & 0.26 & 0.28 & 0.16 & 0.05 & 0.19 & 0.19 & 0.17 & 0.07 \\
DP & 0.83 & 0.87 & 0.76 & 0.56 & 0.69 & 0.54 & 2.04 & 0.56 & 1.08 \\
\hline
\end{tabular}

Figure 1 shows the dispersion diagrams of PROD with FP and DP, respectively.

There is no clear positive trend of the domestic productivity either with FP or DP.

\footnotetext{
${ }^{4}$ Standard deviations across years are, in general, rather small, so that the (row) pattern of the means in Table 2 gives a good approximate picture of the data variation by sector, for each variable.
} 
Actually, in both graphs, there is a strong suggestion of nonlinear effects and a hint of possible outliers.

FIGURE 1. DISPERSION DIAGRAMS

a) FP (horizontal axis) x PROD (vertical axis)

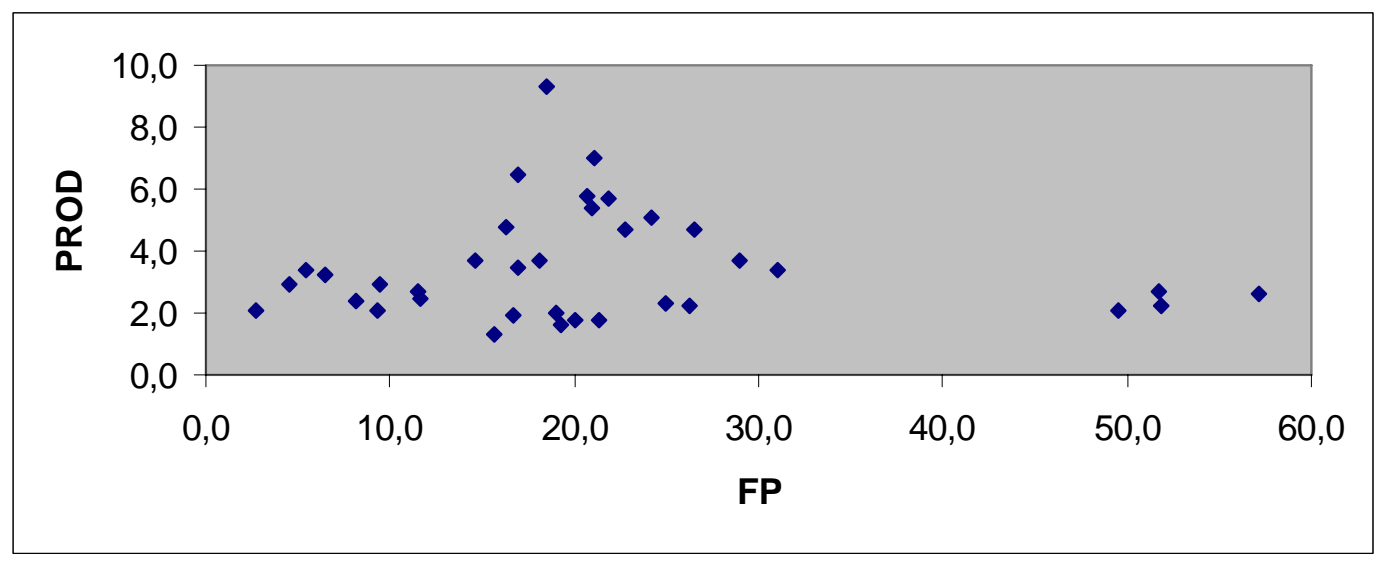

b) DPx100 (horizontal axis) x PROD (vertical axis)

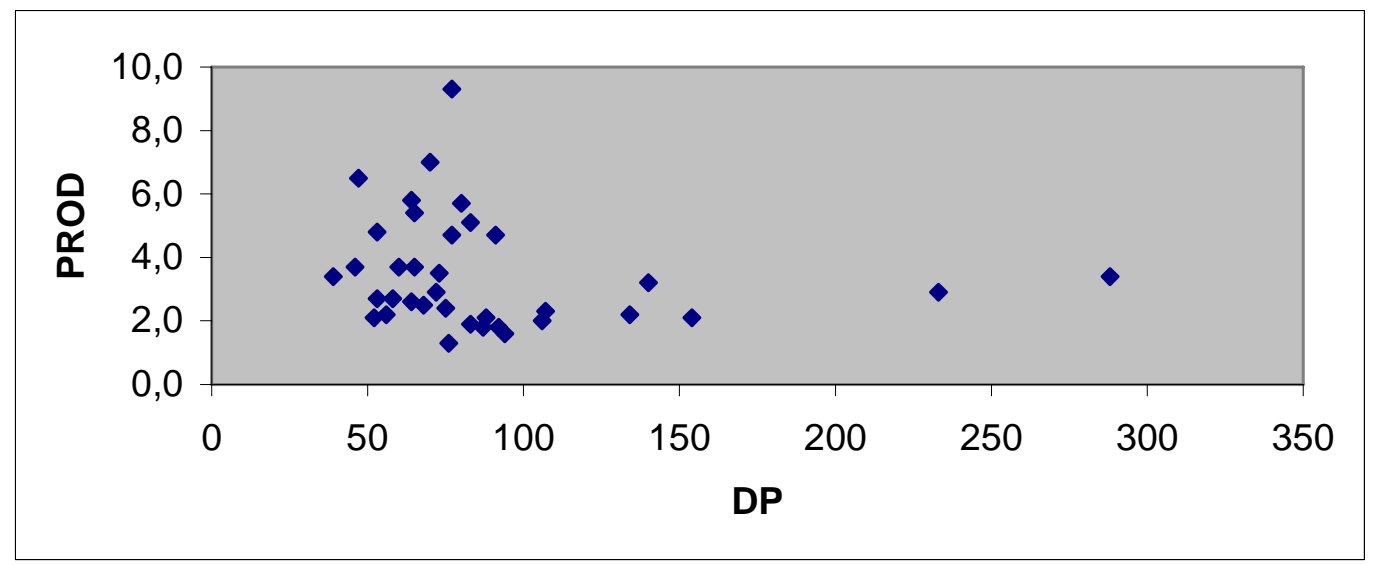

The standard specification

We start with Kokko's (1992) specification, assuming the labour productivity of local firms to be a function of the foreign affiliates'market share and various other industry characteristics. Our dependent variable is thus domestic firms' productivity 
(PROD) and, to account for the spillovers effect, following the common practice, we use the variable foreign presence (FP), previously defined.

With the proviso that labour productivity is at best a partial measure of overall multi-factor productivity ${ }^{5}$, if spillovers occur, there should be higher (domestic) productivity levels in sectors with a larger foreign presence. Variable FP should then have a significant positive coefficient.

As the amount of technology that could potentially spill over to local firms is probably not exogenously given, but dependent on both host country and industry characteristics, we chose as control variables the skill of the labour force (SL), the capitalistic intensity $(\mathrm{CI})$, and proxies for the degree of competition $(\mathrm{H})$ and the level of economies of scale of domestic firms (SE). The first three variables are computed using all firms in the sector, though it could appear more appropriate to build them especially SL and CI - using domestic firms only, as our purpose is to control for influences on domestic productivity. Data limitations did not afford it. In any case, the overall sectoral figures inform about the "environment" domestic firms face and seem acceptable if the results ' interpretation is properly done.

We expect a positive relation between SL, SE, CI and domestic productivity. On what concerns variable $\mathrm{H}$, it measures the degree of (producers') concentration in each industry and is included to account for the effect of market power on the value of productivity. It is generally agreed that more concentrated industries are better able to engage in monopoly pricing and should therefore display higher labour productivity. However, if the larger firms are foreign, which is mostly the case in Portugal, this relation may not occur. Besides, a high concentration level may imply that, due to limited competition, there are not conditions favourable to the spillovers diffusion. In 
extreme cases, it is even possible that the foreign (sub-)sector performs as an enclave, producing a dual structure at the sectoral level. The expected sign for $\mathrm{H}$ is then not predefined.

The following equation was our starting point:

$$
\mathrm{PROD}_{\mathrm{it}}=\alpha+\beta_{1} \mathrm{FP}_{\mathrm{it}}+\beta_{2} \mathrm{CI}_{\mathrm{it}}+\beta_{3} \mathrm{SE}_{\mathrm{it}}+\beta_{4} \mathrm{H}_{\mathrm{it}}+\beta_{5} \mathrm{SL}_{\mathrm{it}}+\epsilon_{\mathrm{it}}
$$

where $\in_{\mathrm{it}}$ refers to the disturbance term for the ith unit (sector) at time (year) t.

If we assume that the disturbances are uncorrelated through time and units, and conditioned on the explanatory variables - identically distributed with a zero mean, this is a pooled regression model which can be consistently and efficiently estimated by ordinary least squares. Table 3, column (1), displays the results of this estimation. The only positive determinants on domestic productivity are the capitalistic intensity and the skilled labour variables. The concentration index is significant but with a negative sign. The foreign presence is not significant and thus the expected spillover effect is not confirmed.

\section{THE INFLUENCE OF THE TECHNOLOGICAL GAP}

\section{The gap and foreign presence}

One reason for the absence of a significant effect of foreign investment on the productivity level could be a dynamic interaction between FP and PROD which can not be analysed within the short time period available. But the lack of a general relationship can also be due to the role of the technology gap between domestic and foreign-owned

\footnotetext{
${ }^{5}$ A concept which takes into account the combined productivity of the firm when all inputs are included.
} 
firms. Kokko (1992), after Findlay (1978), pointed out that spillovers must be related to the technological level of multinationals' affiliates compared to that of domestic firms. Two opposing arguments can be found concerning the effect of this gap on actual technology transfer. If the technological capabilities gap between the two sets of firms is too large, domestic firms may not be able to benefit from the introduction of new technology. In fact, the affiliates' technology may be too advanced to allow for any interaction with local firms, so that higher technology gaps only serve to insulate the affiliates. On the other hand, if the gap is too small, foreign investment may transmit few benefits to domestic firms. A certain distance (in technology) appears then necessary for spillovers to occur as, for instance, when local firms copy foreign procedures or benefit from the training of local employees.

TABLE 3

SPILLOVERS AND THE TECHNOLOGICAL GAP

\begin{tabular}{cccc} 
Indep. Variables & $(1)$ & $(2)$ & $(3)$ \\
\hline $\mathrm{C}$ & 1.19 & .06 & .30 \\
$\mathrm{FP}$ & $(2.57)$ & $(.06)$ & $(.46)$ \\
& 0.86 & 2.41 & \\
$\mathrm{CI}$ & $(1.44)$ & $(1.68)$ & .12 \\
& .089 & .11 & $(3.23)$ \\
$\mathrm{SE}$ & $(3.17)$ & $(3.11)$ & .93 \\
& -.82 & .45 & $(.53)$ \\
$\mathrm{H}$ & $(0.48)$ & $(.24)$ & -4.24 \\
& -3.43 & -5.13 & $(2.97)$ \\
$\mathrm{SL}$ & $(3.20)$ & $(2.58)$ & 2.47 \\
& 2.95 & 2.75 & $(2.01)$ \\
DP & $(2.54)$ & $(2.28)$ & \\
& & .66 & 4.08 \\
FPxDP & & $(1.25)$ & $(1.96)$ \\
& & & .827 \\
$\mathrm{R}^{2}$ & .814 & .828 & .798 \\
Adj R & .783 & .792 & 28.16 \\
F & 26.33 & 23.23 &
\end{tabular}

See Haddad and Harrison (1993) for a firm specific measure of multi-factor productivity. 
We refine our analysis by including variable DP, for the technological gap, in model (1). By assuming that a higher productivity signals a better technology, DP is indeed an indirect measure of the gap; moreover, notice that - for values below 1 - the higher the gap the lower is DP.

The new model is:

$$
\mathrm{PROD}_{\mathrm{it}}=\alpha+\beta_{1} \mathrm{FP}_{\mathrm{it}}+\beta_{2} \mathrm{CI}_{\mathrm{it}}+\beta_{3} \mathrm{SE}_{\mathrm{it}}+\beta_{4} \mathrm{H}_{\mathrm{it}}+\beta_{5} \mathrm{SL}_{\mathrm{it}}+\beta_{6} \mathrm{DP}_{\mathrm{it}}+\epsilon_{\mathrm{it}} \quad,
$$

where $\epsilon_{\text {it }}$ has the same properties as in (1).

Table 1, column (2), displays the estimation results. The proxy for spillovers diffusion, FP, now becomes significant (at the 10 per cent level) and its coefficient also increases. This suggests, in the line of Kokko's (1992) chapter 5, that the technological gap is indispensable for the spread of FDI indirect effects. However, the very coefficient of the proxy for the technological gap, though positive, is not significant.

Reminding that, even if FP is high, a high gap (i.e. a low DP) would not be favourable to spillovers, and taking into account the patterns in Figures 1 and 2, we built a new variable to portray the interaction between FP and DP: FPxDP. Several modelling options are available using this interaction term, depending on whether FP and DP themselves are included in the equation. The results do not differ much, and those for the most parsimonious model:

$$
\mathrm{PROD}_{\mathrm{it}}=\alpha+\beta_{1} \mathrm{FPxDP}_{\mathrm{it}}+\beta_{2} \mathrm{CI}_{\mathrm{it}}+\beta_{3} \mathrm{SE}_{\mathrm{it}}+\beta_{4} \mathrm{H}_{\mathrm{it}}+\beta_{5} \mathrm{SL}_{\mathrm{it}}+\epsilon_{\mathrm{it}}
$$

are displayed in column (3) of Table 3. The cross-effect is clearly confirmed.

The gap range 
If the technological gap matters, the fact that it is not significant in model (2) can also be associated to its different levels across sectors. The question we then seek to answer is how wide could the gap be in order to (i) have a positive effect; (ii) maximize the spillovers diffusion. Consequently, a test of the sensitivity of the model to alternative ranges for the gap was performed.

"Cutting" variable DP outside pre-set ranges created several alternatives. If we define a dummy with value one whenever the DP values are within the pre-defined range and zero otherwise, the "cut variable" is equal to the dummy times DP. The dummy itself $\left(\mathrm{D}_{\mathrm{it}}\right)$ has also been included in the model, to allow for extra flexibility:

$$
\mathrm{PROD}_{\mathrm{it}}=\alpha+\beta_{1} \mathrm{FP}_{\mathrm{it}}+\beta_{2} \mathrm{CI}_{\mathrm{it}}+\beta_{3} \mathrm{SE}_{\mathrm{it}}+\beta_{4} \mathrm{H}_{\mathrm{it}}+\beta_{5} \mathrm{SL}_{\mathrm{it}}+\beta_{6} \mathrm{D}_{\mathrm{it}}+\beta_{7} \mathrm{DPxD} \mathrm{D}_{\mathrm{it}}+\epsilon_{\mathrm{it}} .
$$

Table 4 shows the results for the different ranges tried. The domestic performance variables within a lower bound of 40 per cent are not significant, signalling that the gap cannot be too high. The best results occur for the 50-80 per cent range, where the cross-product coefficient $\left(\beta_{7}\right)$ has a higher impact, as well as displaying the highest $t$-value. We keep this range for further specifications of the model.

It must however be pointed that the $50-80$ per cent range, being a data-driven finding, should not be taken as an "optimal range", even for the Portuguese reality. What this exercise confirms is the key role of the gap range for ensuring the occurrence of spillovers ${ }^{6}$. Moreover, identification of the four constituent parts accounting for the gap effect, Narula (2004), is still open.

\footnotetext{
${ }^{6}$ Model (4) does not include DP itself as an independent variable. Though a possible specification, we favoured those without it to characterise that it is indeed a "new variable" - the gap within a restricted range - which plays a role in the phenomenon we try to explain.
} 
TABLE 4

TESTING ALTERNATIVE RANGES FOR THE TECHNOLOGICAL GAP

\begin{tabular}{|c|c|c|c|c|c|}
\hline Indep. Variables & $40-80 \%$ & $40-95 \%$ & $50-80 \%$ & $50-95 \%$ & $60-95 \%$ \\
\hline $\mathrm{C}$ & $\begin{array}{c}.89 \\
(1.70)\end{array}$ & $\begin{array}{c}0.83 \\
(1.60)\end{array}$ & $\begin{array}{c}.80 \\
(1.30)\end{array}$ & $\begin{array}{c}.69 \\
(1.29)\end{array}$ & $\begin{array}{c}.86 \\
(1.91)\end{array}$ \\
\hline FP & $\begin{array}{c}2.57 \\
(1.58)\end{array}$ & $\begin{array}{c}2.15 \\
(1.51)\end{array}$ & $\begin{array}{c}2.99 \\
(2.39)\end{array}$ & $\begin{array}{c}2.37 \\
(2.38)\end{array}$ & $\begin{array}{c}1.39 \\
(1.71)\end{array}$ \\
\hline $\mathrm{CI}$ & $\begin{array}{c}.11 \\
(2.70)\end{array}$ & $\begin{array}{c}.11 \\
(2.87)\end{array}$ & $\begin{array}{c}.09 \\
(3.85)\end{array}$ & $\begin{array}{c}.10 \\
(3.14)\end{array}$ & $\begin{array}{c}.10 \\
(3.57)\end{array}$ \\
\hline SE & $\begin{array}{l}-.88 \\
(.47)\end{array}$ & $\begin{array}{l}-1.24 \\
(.49)\end{array}$ & $\begin{array}{l}-1.37 \\
(.75)\end{array}$ & $\begin{array}{r}-1.07 \\
(.45)\end{array}$ & $\begin{array}{l}-1.95 \\
(.87)\end{array}$ \\
\hline $\mathrm{H}$ & $\begin{array}{l}-3.70 \\
(2.58)\end{array}$ & $\begin{array}{l}-3.51 \\
(2.58)\end{array}$ & $\begin{array}{l}-2.56 \\
(2.98)\end{array}$ & $\begin{array}{l}-2.95 \\
(3.40)\end{array}$ & $\begin{array}{l}-3.06 \\
(3.22)\end{array}$ \\
\hline SL & $\begin{array}{c}2.29 \\
(1.50)\end{array}$ & $\begin{array}{c}2.45 \\
(1.72)\end{array}$ & $\begin{array}{c}3.16 \\
(2.71)\end{array}$ & $\begin{array}{c}3.24 \\
(2.39)\end{array}$ & $\begin{array}{c}2.93 \\
(2.41)\end{array}$ \\
\hline D40/80 & $\begin{array}{l}-3.45 \\
(1.81)\end{array}$ & & & & \\
\hline D40/80.DP & $\begin{array}{c}4.97 \\
(1.80)\end{array}$ & & & & \\
\hline D40/95 & & $\begin{array}{l}-2.03 \\
(1.71)\end{array}$ & & & \\
\hline D40/95.DP & & $\begin{array}{c}2.88 \\
(1.89)\end{array}$ & & & \\
\hline D50/80 & & & $\begin{array}{l}-6.18 \\
(3.42)\end{array}$ & & \\
\hline D50/80.DP & & & $\begin{array}{c}8.85 \\
(3.46)\end{array}$ & & \\
\hline D50/95 & & & & $\begin{array}{l}-3.11 \\
(2.78)\end{array}$ & \\
\hline D50/95.DP & & & & $\begin{array}{c}4.15 \\
(2.71)\end{array}$ & \\
\hline D60/95 & & & & & $\begin{array}{l}-3.58 \\
(2.06)\end{array}$ \\
\hline D60/95.DP & & & & & $\begin{array}{c}5.01 \\
(2.23)\end{array}$ \\
\hline $\mathrm{R}^{2}$ & .853 & .840 & .894 & .858 & .852 \\
\hline Adj. $R^{2}$ & .816 & .780 & .868 & .823 & .815 \\
\hline $\mathrm{F}$ & 23.12 & 20.98 & 33.86 & 24.26 & 23.04 \\
\hline
\end{tabular}

t-values (between brackets) using White's heteroscedasticity correction.

\section{VARIABLE SPILLOVER COEFFICIENTS}

In the previous specifications the vector of parameters $\beta$ is assumed constant through all sectors and years. In the case of the variable FP this does not seem to be reasonable because its values are quite differentiated along the sectors. Basic statistics (see Table 2) show a sector with a high weight of foreign affiliates (sector 38, which 
includes machinery and transport equipment), two with a low weight (sectors 33, wood and cork, and 37, basic metallurgy), and the remaining ones with values for foreign presence around the global average.

We estimated the influence of foreign presence disaggregating FP in model (4) according to the above grouping:

$$
\mathrm{FP}=\mathrm{FP} 1+\mathrm{FP} 2+\mathrm{FP} 3,
$$

where FP1 includes only sector 38, FP2 sectors 33 and 37 and FP3 the remaining ones $(31,32,34,35,36$ and 39). This means that, for instance, whenever an observation is related to sector 38, FP2 and FP3 are zero, while FP1 equals the value of foreign presence for the corresponding year. The resulting model is:

$$
\begin{aligned}
\mathrm{PROD}_{\mathrm{it}}=\alpha & +\beta_{1} \mathrm{FP} 1_{\mathrm{it}}+\beta_{2} \mathrm{FP} 2_{\mathrm{it}}+\beta_{3} \mathrm{FP} 3_{\text {it }}+\beta_{4} \mathrm{CI}_{\mathrm{it}}+\beta_{5} \mathrm{SE}_{\mathrm{it}}+\beta_{6} \mathrm{H}_{\mathrm{it}}+\beta_{7} \mathrm{SL}_{\mathrm{it}}+\beta_{8} \mathrm{D} 50 / 80_{\text {it }} \\
& +\beta_{9} \mathrm{D} 50 / 80 \mathrm{xDP} \mathrm{it}_{\mathrm{it}}+\in_{\mathrm{it}}
\end{aligned}
$$

Results are shown in Table 5, column (1). We also tried out a different grouping, including sector 38 in the largest previous group (variable FP3*), with results in column (2). In the first case, only sector 38 presents positive, significant spillovers, an expected result due to the high share of foreign presence in it (52.5 on average). The influence of sector 38 is confirmed in the second grouping.

Beyond interacting in a complex way with the gap, the spillover effect is also a function of particular sectoral characteristics. The "global" or general spillover effects found in many empirical works are simply confounding different sector dynamics. 
TABLE 5

PANEL DATA: DIFFERENT GROUPS OF SECTORS FOR FP

\begin{tabular}{ccc} 
Indep. Variables & $(1)$ & $(2)$ \\
\hline $\mathrm{C}$ & 1.37 & .79 \\
$\mathrm{CI}$ & $(1.53)$ & $(1.16)$ \\
& .010 & .09 \\
$\mathrm{SE}$ & $(3.92)$ & $(3.84)$ \\
& -1.75 & -1.40 \\
$\mathrm{H}$ & $(.84)$ & $(.74)$ \\
& -3.42 & -2.58 \\
$\mathrm{SL}$ & $(2.93)$ & $(3.07)$ \\
& 3.05 & 3.17 \\
D50/80 & $(2.46)$ & $(2.62)$ \\
& -7.10 & -6.18 \\
D50/80DP & $(2.99)$ & $(3.29)$ \\
& 9.99 & 8.85 \\
FP1 & $(3.07)$ & $(3.38)$ \\
& 3.08 & \\
FP2 & $(1.83)$ & 3.44 \\
& -1.01 & $(.61)$ \\
FP3 & $(.16)$ & \\
& .52 & 3.03 \\
FP3* & $(.21)$ & $(1.89)$ \\
& & .894 \\
$\mathrm{R}^{2}$ & & .863 \\
Adj. R & .899 & 28.55 \\
F & .865 & \\
\hline t-values (between brackets) & 25.86 & \\
& & \\
& &
\end{tabular}

\section{A FIXED EFFECTS MODEL}

It is possible that a myriad of influences on productivity - like those related to the "software" environment for spillovers mentioned by Kokko, as well as to other sectoral specifics - are not included in the right-hand-side of our equations. These missing or unobserved variables can be assumed to express the heterogeneity of the individual units, but to be constant over time. A common formulation of such a model states that differences across units can be captured in differences in the constant term. It can be written as:

$$
\mathrm{PROD}_{\mathrm{it}}=\beta_{1} \mathrm{FP}_{\mathrm{it}}+\beta_{2} \mathrm{CI}_{\mathrm{it}}+\beta_{3} \mathrm{SE}_{\mathrm{it}}+\beta_{4} \mathrm{H}_{\mathrm{it}}+\beta_{5} \mathrm{SL}_{\mathrm{it}}+\beta_{6} \mathrm{D}_{\mathrm{it}}+\beta_{7} \mathrm{DPxD} \mathrm{D}_{\mathrm{it}}+\epsilon_{\mathrm{it}}
$$


where $\epsilon_{\mathrm{it}}=\alpha_{\mathrm{i}}+\eta_{\mathrm{it}}$, with the $\eta_{\mathrm{it}}$ zero-mean, constant variance shocks uncorrelated across time and units, and the $\alpha_{\mathrm{i}}$ being the unknown individual effects to be estimated for each unit (sector) i.

The individual effects may be either fixed or random. In the latter case, though the $\alpha_{i}$ must be uncorrelated with the explanatory variables, the errors in (6) will be correlated within sectors. However, when the random effects model is valid, the fixed effects estimator will still produce consistent estimates of the identifiable parameters ${ }^{7}$. If the number of units is small enough, model (6), under the fixed effects assumption, can be estimated by ordinary least squares with one column for each sectoral dummy. Moreover, a fixed effects approach makes also sense if one considers that the nine sectors being studied are a full partition of all manufacturing.

The estimation results are reported in Table 6. It is interesting to compare the coefficients in this table with those in the related column of Table 4 . The four significant independent variables' coefficients in the fixed-effects model are as well in Table 4, with the same signs and, but for the concentration index $(\mathrm{H})$, roughly the same value. Two major changes then occur for variables FP and SL: their coefficients change sign and become not significant. On the other hand, all idiosyncratic effects are positive and significant - most at the 1 per cent level - showing that there clearly exists a sectoral effect. Indeed, it seems to be more important than those previously accounted for the foreign presence (FP) and the skilled labour ratio (SL). In other words, they leave no room for spillover effects.

\footnotetext{
${ }^{7}$ See any econometrics textbook, as Johnston and Dinardo (1997), or Judge et al. (1985).
} 
TABLE 6

FIXED EFFECTS MODEL - LEAST SQUARES ESTIMATION

\begin{tabular}{|c|c|}
\hline Independent Variables & Coefficients \\
\hline $\mathrm{FP}$ & $\begin{array}{l}-5.16 \\
(1.71)\end{array}$ \\
\hline CI & $\begin{array}{l}.17 \\
(3.56)^{* * *}\end{array}$ \\
\hline SE & $\begin{array}{l}-4.36 \\
(1.06)\end{array}$ \\
\hline $\mathrm{H}$ & $\begin{array}{l}-8.84 \\
(3.88) * * *\end{array}$ \\
\hline SL & $\begin{array}{l}-3.25 \\
(.92)\end{array}$ \\
\hline D31 & $\begin{array}{l}6.99 \\
(3.95)^{* * *}\end{array}$ \\
\hline D32 & $\begin{array}{l}3.95 \\
(3.26)^{* * *}\end{array}$ \\
\hline D33 & $\begin{array}{l}3.50 \\
(2.78) * *\end{array}$ \\
\hline D34 & $\begin{array}{l}5.32 \\
(2.49)^{* *}\end{array}$ \\
\hline D35 & $\begin{array}{l}6.13 \\
(2.94) * * *\end{array}$ \\
\hline D36 & $\begin{array}{l}4.11 \\
(3.37)^{* * * *}\end{array}$ \\
\hline D37 & $\begin{array}{l}5.25 \\
(3.28)^{* * *}\end{array}$ \\
\hline D38 & $\begin{array}{l}8.52 \\
(3.90)^{* * * *}\end{array}$ \\
\hline D39 & $\begin{array}{l}3.73 \\
(4.15)^{* * *}\end{array}$ \\
\hline D50/80 & $\begin{array}{l}-5.14 \\
(2.79)^{* * *}\end{array}$ \\
\hline D50/80DP & $\begin{array}{l}7.27 \\
(2.89)^{* * * *}\end{array}$ \\
\hline $\mathrm{R}^{2}$ & .957 \\
\hline Adj $R^{2}$ & .924 \\
\hline $\mathrm{F}$ & 29.52 \\
\hline
\end{tabular}

Table 7 presents the results of two tests. The first is a standard F test to check the null hypothesis that the sectoral effects are all equal. Under this null, the efficient estimator is a pooled least squares, and the ratio:

$$
\mathrm{F}_{\mathrm{n}-1, \mathrm{nT}-\mathrm{n}-\mathrm{k}}=\left[\left(\mathrm{R}_{\mathrm{u}}^{2}-\mathrm{R}_{\mathrm{r}}^{2}\right) /\left(1-\mathrm{R}_{\mathrm{u}}^{2}\right)\right] \times[(\mathrm{nT}-\mathrm{n}-\mathrm{k}) /(\mathrm{n}-1)]
$$

where $\mathrm{u}$ indicates the unrestricted model, $\mathrm{r}$ the restricted one, $\mathrm{n}$ stands for the number of 
units, $\mathrm{T}$ for that of periods and $\mathrm{k}$ for the number of explanatory variables, is asymptotically an F. In our case, the corresponding lines in Tables 4 and 6 provide the $\mathrm{R}^{2}$ values for computing the $\mathrm{F}_{8,20}$ statistic. The null is clearly rejected at 1 per ecnt.

The second is the Hausman test statistic, which tests the hypothesis that the (random) effects are uncorrelated with the explanatory variables. Though the null is not rejected $^{8}$, the fact that the random effects model "passes" the test may indicate that, for instance, there is not enough variation in the explanatory variables to provide results precise enough to distinguish between the two sets of estimates (see Johnston and Dinardo,1997, p. 404).

TABLE 7

TWO TESTS ON THE FIXED EFFECTS MODEL

\begin{tabular}{cc}
\hline F-test on equality of effects & $\mathrm{F}_{8,20}=3.66^{* * *}$ \\
Hausman test & $\chi^{2}{ }_{8}=8.80$ \\
\hline
\end{tabular}

There are thus significant sector specific effects to be considered when explaining the productivity variation. Indeed, the inclusion of sectoral dummies, by purging the other coefficients of all unaccounted for (sector) idiosyncrasies, apparently changes the empirical role of foreign presence in domestic productivity. Moreover, the adjusted $\mathrm{R}^{2}$ increases from 0.868 in Table 4 to 0.924 in Table 6 .

Combining this with the result in the previous section raises an important issue: not only the spillover effect varies with sectors, but due consideration of full sectoral specificities - in a model using structural characteristics as other explanatory variables annihilates the global spillover effect. Two points then ensue. First, dealing with the sectoral dimension requires other variables than those used so far in the literature. 
Second, supposing the right variables are found and included, the "spillovers question" must be reopened. In the remaining of this paper we shall not pursue this line but rather, still at a product market level, will try to find additional explanations for this key sectoral influence.

\section{INTER-SECTORAL SPILLOVERS AND AGGLOMERATION EFFECTS}

Table 8 shows the correlation coefficients for the residuals in model (2), computed on a sectoral basis. Given that the residuals account for unexplained productivity shocks, a high positive correlation would signal a common (hidden) effect on the two sectors' productivity. By the same token, high negative correlations would mean opposing factors in the sectors performance.

The residuals' correlations computed from models (2) to (4) show an interesting, relatively stable pattern. If we consider only those higher than 0.5 in absolute value, all negative correlations but one are associated with the non-metallic (36) sector, which opposes five others. Within the positive links, two groups stand out: textiles (32) and wood and cork (33), both traditional manufactures with a strong historical presence in the Portuguese economy; and chemicals (35), paper (34), metallurgy (37) and transport (38), modern sectors with significant market linkages. Food (31) is also worth mentioning, due to its relevant positive correlation linkages to five sectors.

Given the product diversity within each sector, these results may be partially due to the high aggregation level of our study, but they also suggest an identity of reaction to other factors. We venture that such factors are a combination of centrifugal and centripetal effects, in the lines of Fujita et al. (1999), responsible for agglomerations like the one in the Greater Lisbon industrial area, where many firms are located.

\footnotetext{
${ }^{8}$ This is also an asymptotic test to be taken with care, given our sample size.
} 
Agglomeration is viewed here as source of external economies of scale, the hypothesis being that the profitability of each firm can be higher if others are nearby. This could come through either vertical linkages - i.e., it is advantageous to be near suppliers of intermediates and buyers of final goods -, or horizontal ones, such as direct spillovers between firms and indirect knowledge links established in a common, local pool of skilled labour or specialized management, for instance.

TABLE 8

RESIDUALS ${ }^{\prime}$ CORRELATIONS FOR MODEL (2)

\begin{tabular}{c|cccccccc} 
& 31 & 32 & 33 & 34 & 35 & 36 & 37 & 38 \\
\hline 31 & 1 & & & & & & & \\
32 & .120 & 1 & & & & & & \\
33 & .121 & .607 & 1 & & & & & \\
34 & .719 & .520 & .776 & 1 & & & & \\
35 & .976 & .132 & .299 & .826 & 1 & & & \\
36 & -.978 & -.269 & -.324 & -.848 & -.988 & 1 & & \\
37 & .561 & .167 & .779 & .891 & .727 & -.683 & 1 & \\
38 & .937 & .156 & -.136 & .506 & .840 & -.872 & .245 & 1 \\
39 & .525 & -.225 & -.744 & -.181 & .335 & -.353 &.-392 & .757 \\
\hline
\end{tabular}

As a way to improve the view on the concentration/spread of sectors outside Lisbon, Table 9 shows the location of manufacturing activities in the Portuguese territory, in each of the five major regions (NUTS2 level) of the country.

The basic pattern of the correlations is roughly confirmed in both cases, stressing the economic geography argument. The relatively 'more uniform' spread of the nonmetallic sector, present in areas where many of the others are barely found; the concentration of chemicals, paper, metallurgy, transport and food in the Greater Lisbon, with a secondary focus in the North; and the higher presence of textiles and woodcork (as well as the less informative 'others') in this last region. The conspicuous presence of chemicals in the Greater Lisbon, as expected of a typical intermediate supplier sector, 
and the predominance of traditional manufacturing in the North are further supporting evidences.

TABLE 9

LOCATION OF MANUFACTURING ACTIVITIES IN THE PORTUGUESE TERRITORY, 1993

(\% share of sectoral output)

\begin{tabular}{l|rrrcc} 
& North & Centre & Greater Lisbon & Alentejo & Algarve \\
\hline 31 & 30.05 & 14.09 & 52.44 & 2.56 & 0.86 \\
32 & 80.75 & 8.40 & 10.39 & 0.43 & 0.03 \\
33 & 56.21 & 19.54 & 20.47 & 2.19 & 1.59 \\
34 & 21.77 & 9.24 & 68.03 & 0.58 & 0.38 \\
35 & 12.38 & 7.30 & 79.53 & 0.61 & 0.18 \\
36 & 15.01 & 36.52 & 45.35 & 1.95 & 1.17 \\
37 & 29.11 & 16.99 & 53.44 & 0.46 & 0.00 \\
38 & 35.80 & 12.02 & 50.96 & 0.84 & 0.37 \\
39 & 70.30 & 2.96 & 26.37 & 0.09 & 0.28 \\
\hline \multicolumn{5}{l}{ Source: INE }
\end{tabular}

Another way to confirm that particular industries are associated with particular regions is to compute, for each sector, a Herfindhal spatial concentration index $(\mathrm{H})$ using the shares of sector production in each region. The index provides information on the extent to which each industry is regionally concentrated, but it does not tell about the proximity of the possible agglomerations. As a consequence, two industries may appear equally (geographically) concentrated, one being roughly located in two neighbouring regions and the other split among far distant ones. The spatial separation index (SS) proposed in Midelfart-Knarvik et al. (2000), which is a production-weighted sum of all the bilateral distances between locations (taken as the distance between the most representative cities in each region), was then also computed, as a complementary 
tool. If all production occurs in a single place, SS is zero, and it increases the more spatially separated production is.

The two sets of values in Table 10 broadly suggest, as expected, that regional concentration, in Portugal, decreases as the spatial separation increases. "Non-metallic" (36) is again the least concentrated, reasonably spread sector.

TABLE 10

SPATIAL LOCATION INDEXES, 1993

\begin{tabular}{l|cc} 
& $\begin{array}{c}\text { Spatial } \\
\text { Separation } \\
\text { Index (SS) }\end{array}$ & $\begin{array}{c}\text { Herfindhal } \\
\text { Index } \\
(\mathrm{H})\end{array}$ \\
\hline 31 & 79.5 & 38.6 \\
32 & 38.3 & 67.0 \\
33 & 71.7 & 39.7 \\
34 & 64.7 & 51.9 \\
35 & 45.5 & 65.3 \\
36 & 70.3 & 36.2 \\
37 & 74.7 & 39.9 \\
38 & 78.8 & 40.3 \\
39 & 64.6 & 56.5 \\
\hline
\end{tabular}

Source: INE

Further analytical evidence supporting the geographical dimension is provided by the correlation between the residuals and the Herfindhal spatial concentration index. Table 11 shows the results for models (2), (3), (4) - with the 50/80 range -, and (6), using the NUTS3 level, which increases the number of regions to 28 . The first three values are surprisingly similar and all significantly different from zero. However, for the fixed-effects model the correlation is (statistically) zero.

A hidden spatial dimension, related to the agglomeration pattern of the sectors, seems evident. In models (2), (3) and (4), where no attention to the sectoral component 
is given, part of the residuals dispersion is explained by the spatial index. Interestingly enough, the correlation is negative, signalling perhaps that in the more concentrated sectors other factors had already accounted for the domestic productivity; the standard model we use overemphasizing the role of the foreign presence. Inclusion of the sector specificities in (6) brings within it this hidden spatial dimension, and the correlation falls to zero.

TABLE 11

CORRELATIONS BETWEEN THE RESIDUALS AND THE SPATIAL CONCENTRATION INDEX

\begin{tabular}{cc} 
Models & Correlation \\
\hline$(2)$ & -0.411 \\
$(3)$ & -0.414 \\
$(4)$ & -0.391 \\
$(6)$ & 0.021 \\
\hline
\end{tabular}

Overall, on exploratory grounds - given the reduced number of years in our panel -, the residuals analysis adds interesting notes to the debate. Specific spatial relations between groups of industries are suggested, and maybe a sharper characterisation of the technological level of each sector - allowing to separate less advanced, more traditional sectors from more modern ones - is missing. The aggregation level of the study puts a grain of doubt on the utility and feasibility of constructing this new explanatory (and likely omitted) variable here.

The suggestion of agglomeration effects finds support, in a much larger spatial dimension, in the preliminary evidence produced by Barrell and Pain (1999) on the concentration of the stock of US manufacturing FDI in Europe, and location effects, in a broader sense, are also attracting the attention of others, like Bell and Marin (2004). 


\section{CONCLUSIONS}

The basic message is that the relationship between domestic firms productivity and the foreign presence is a complex one, being only revealed if the proper controls on these two variables are used.

In broad terms, FDI spillovers were shown to be associated to modern industries in which the foreign owned establishments have a clear, but not too sharp, edge on the domestic ones. It is possible that, though present, spillovers are sometimes not identified simply because they are not increasing linearly with the foreign presence. This nonlinearity is suggested by the fact that a technological gap seems to be a condition for spillovers, but only within a certain range. We showed this, first by detecting a significant interaction between these two variables and then by progressively arriving at "an optimal gap range" for spillovers.

But another crucial influence, of a sectoral nature, is present. Indeed, for many sectors, even within the "optimal range", spillovers do not take place. They seem to occur in modern sectors, with large-scale gains and relatively new in the country. The results of the fixed-effects model clearly indicate that other variables are needed to account for these differences, as also supported by the residuals analysis. The exploratory analysis of inter-sectoral spillovers suggests that agglomeration characteristics can be one relevant determinant.

Our results re-stress the interest of analysing the spillovers of foreign affiliates by incorporating both intra and inter externalities in the same model, as well as other, more specific sector-discriminating factors. The importance for development strategies is immediate. Foreign direct investment policies, aiming solely at spillovers effects, as if they would nearly inevitably take place, can lead to huge disappointments, even in an 
economy embedded in a developed environment, as Portugal. Due consideration of the spatial dimension, and a finer analysis of the inter-sectoral dynamics are equally important. Once again, development planning emerges as a needed complement to irrestrict openness. Further research must also be pursued, with disaggregated data at the firm level, to confirm our findings within this much more heterogeneous realm.

\section{APPENDIX}

General description of the nine manufacturing sectors (between brackets appears the name they are usually referred to in the text, if different from the description)

31: Food and tobacco

32: Textiles, clothing and leather goods

33: Wood and cork

34: Paper, printing and publishing

35: Chemicals, rubber and plastics (chemicals)

36: Minerals, non metallic

37: Basic metallurgy

38: Steel goods, machines and transport material

39: Other manufactures

\section{References}

Audretsch, D. (1998), "Agglomeration and the Location of Innovative Activity", Oxford Review of Economic Policy, 14, pp. 18-29.

Audretsch, D. and Feldman, M.(1996), "Knowledge Spillovers and the Geography of Innovation and Production", American Economic Review, 86, pp.630-640.

Aitken, B. and Harrison, A. (1999), "Do Domestic Firms Benefit form Foreign Direct Investment", American Economic Review, 89 (3), pp. 605-618. 
Barrel, R. and Pain, N. (1999), "Domestic Institutions, Agglomerations and Foreign Direct Investment in Europe", European Economic Review, vol. 43, pp. 925934.

Barrios, S. e Strobl, E. (2002), "Foreign Direct Investment and Productivity Spillovers: Evidence from the Spanish Experience", Weltwirtschaftliches Archiv, 138(3), pp. 459 - 481 .

Bell, M. and A. Marin (2004), Where the foreign direct investment related technology spillovers come from in emerging economies? An exploration in Argentina in the 1990s. European Journal of Development Research, 16(3); 653-86.

Borensztein, E., J. de Gregorio and J. W. Lee (1998), How does foreign direct investment affect economic growth ? Journal of International Economics, vol. 45; pp. 115-35.

Crespo, N. and Fontoura, M.P. (2006a), "Determinant Factors of FDI Spillovers-What Do We Really Know?", World Economy, forthcoming.

Crespo, N. and Fontoura, M. P. (2006b) "30 Anos de Investigação sobre Externalidades do IDE para as Empresas Domésticas-Que Conclusões?” Working Paper, 2/2006/DE/CISEP,ISEG, Technical University of Lisboa, Department of Economics.

Damijan, J., M. Knell, B. Majcen e Rojec, M. (2003), “Technology Transfer Through FDI In Top-10 Transition Countries: How Important Are Direct Effects, Horizontal and Vertical Spillovers?", William Davidson Working Paper 549.

Farinha, F. and Mata, J. (1996), "The Impact of Foreign Direct Investment in the Portuguese Economy", W/P n ${ }^{\circ} 16 / 96$, Bank of Portugal.

Findlay, R. (1978), Relative backwardness, direct foreign investment and the transfer of technology: a simple dynamic model. Quarterly Journal of Economics, vol. 29; pp. 1-15.

Flôres, R. G. Jr, Fontoura, M. and Santos, R. (2002), "Foreign Direct Investment and Spillovers: Additional Lessons from a Country Study", Ensaios Economicos, EPGE/FGV, nº 455. Fundação Getúlio Vargas, Rio de Janeiro.

Fujita, M. Krugman, P and Venables, A. (1999), The Spatial Economy-Cities, Regions and International Trade, The MIT Press, Cambridge

Girma, S. (2003), “ Absorptive Capacity and Productivity Spillovers from FDI: a Threshold Regression Analysis", Working Paper 25/2003. European Economy Group. 
Girma, S. and Wakelin, K. (2001), "Regional Underdevelopment: Is FDI the Solution?

A Semi-Parametric Analysis", GEP Research Paper 2001/11. University of Nottingham.

Görg, H. and Greenaway, D. (2004), "Much Ado About Nothing? Do Domestic Firms Really Benefit from Foreign Direct Investment?, The World Bank Research Observer, 19(2), pp. 171-197.

Görg, H. and F. Ruane (1998), Linkages between Multinationals and Indigenous Firms:

Evidence for the Electronics Sector in Ireland. Trinity Economic Paper Series, Technical Paper ${ }^{\circ}$ 98/13.

Javorcik, B. (2004), "Does Foreign Direct Investment Increase the Productivity of Domestic Firms? In Search of Spillovers Through Backward Linkages", American Economic Review, 94 (3), pp. 605-627.

Johnston, J. and J. Dinardo (1997) Econometric Methods, $4^{\text {th }}$ ed., McGraw-Hill.

Jordaan, J. (2005). Determinants of FDI-Induced Externalities: New Empirical Evidence for Mexican Manufacturing Industries. World Development, 33 (12), 2103-2118.

Judge, G. G., W. E. Griffiths, R. Carter Hill, H. Lütkepohl and Lee, T.-C.. (1985), The Theory and Practice of Econometrics, $2^{\text {nd }}$ ed. New York, John Wiley \& Sons.

Kinoshita, Y. (2001), "R\&D and Technology Spillovers Through FDI: Innovation and Absorptive Capacity”, CEPR Discussion Paper, nº 2775.

Kokko, A. (1992), Foreign Direct Investment, Host Country Characteristics, and Spillovers, Ph. D. Thesis, Stockholm School of Economics.

Kugler, M. (2005), "Spillovers from Foreign Direct Investment: Whithin or Between Industries", Borradores de Economia,369, Banco de la Republica de Colombia..

Lall, S. and R. Narula. (2004). Foreign Direct Investment and its role in economic development: do we need a new agenda ? European Journal of Development Research, 16(3); 447-64.

Mateus, A. M. 1998. Economia Portuguesa. Lisbon, Editorial Verbo.

Midelfart-Knarvik, K.H., Overman, H.G., Redding, S. J. and Venables, A. (2000). "The Location of European Industry" Report for the Directorate General for Economic and Financial Affairs, European Commission.

Narula, R. (2004), "Understanding Absorptive Capacities in an Innovation Systems Context: Consequences for Economic and Employment Growth", Merit Research Memorandum 2004-003. 
Narula, R and Marin, A. (2003), "FDI spillovers, Absorptive Capacities and Human Capital Development: Evidence from Argentina”, Merit Research Memorandum 2003-016.

Proença, I, Fontoura. M. P. and Crespo, N. (2006), "Productivity Spillovers from Multinational Corporations: Vulnerability to Deficient Estimation", Applied Econometrics and International Development, forthcoming.

Santos, V. (1991), "Investimento estrangeiro e a eficiência da indústria portuguesa", Estudos de Economia, vol. XI, nº 2, March, pp. 181-201.

Schoors, K. e van der Tol, B. (2002), "Foreign Direct Investment Spillovers Within and Between Sectors: Evidence from Hungarian Data", Working Paper 2/157, Faculty of Economics and Business Administration, University of Gent, Belgium.

Sinani, E. and Meyer, K. (2004), "Spillovers of Technology Transfer from FDI: the Case of Estonia", Journal of Comparative Economics, 32, pp. 445-466.

Torlak, E. (2004), "Foreign Direct Investment, Technology Transfer, and Productivity Growth in Transition Countries - Empirical Evidence from Panel Data." Cege Discussion Paper 26.

Yudaeva, K., K. Kozlov, N. Malentieva e Ponomareva, N. (2003), "Does Foreign Ownership Matter? The Russian Experience”, Economics of Transition, 11(3), pp. $383-409$. 


\section{Últimos Ensaios Econômicos da EPGE}

[593] Luiz Renato Regis de Oliveira Lima e Raquel Menezes Bezerra Sampaio. The Asymmetric Behavior of the U.S. Public Debt.. Ensaios Econômicos da EPGE 593, EPGE-FGV, Jul 2005.

[594] Pedro Cavalcanti Gomes Ferreira, Roberto de Góes Ellery Junior, e Victor Gomes. Produtividade Agregada Brasileira (1970-2000): declínio robusto e fraca recuperação. Ensaios Econômicos da EPGE 594, EPGE-FGV, Jul 2005.

[595] Carlos Eugênio Ellery Lustosa da Costa e Lucas Jóver Maestri. The Interaction Between Unemployment Insurance and Human Capital Policies. Ensaios Econômicos da EPGE 595, EPGE-FGV, Jul 2005.

[596] Carlos Eugênio Ellery Lustosa da Costa. Yet Another Reason to Tax Goods. Ensaios Econômicos da EPGE 596, EPGE-FGV, Jul 2005.

[597] Marco Antonio Cesar Bonomo e Maria Cristina Trindade Terra. Special Interests and Political Business Cycles. Ensaios Econômicos da EPGE 597, EPGE-FGV, Ago 2005.

[598] Renato Galvão Flôres Junior. Investimento Direto Estrangeiro no Mercosul: Uma Visão Geral. Ensaios Econômicos da EPGE 598, EPGE-FGV, Ago 2005.

[599] Aloisio Pessoa de Araújo e Bruno Funchal. Past and Future of the Bankruptcy Law in Brazil and Latin America. Ensaios Econômicos da EPGE 599, EPGEFGV, Ago 2005.

[600] Marco Antonio Cesar Bonomo e Carlos Carvalho. Imperfectly Credible Disinflation under Endogenous Time-Dependent Pricing. Ensaios Econômicos da EPGE 600, EPGE-FGV, Ago 2005.

[601] Pedro Cavalcanti Gomes Ferreira. Sobre a Inexistente Relação entre Política Industrial e Comércio Exterior. Ensaios Econômicos da EPGE 601, EPGEFGV, Set 2005.

[602] Luiz Renato Regis de Oliveira Lima, Raquel Sampaio, e Wagner Gaglianone. Limite de Endividamento e Sustentabilidade Fiscal no Brasil: Uma abordagem via modelo Quantílico Auto-Regressivo (QAR). Ensaios Econômicos da EPGE 602, EPGE-FGV, Out 2005.

[603] Ricardo de Oliveira Cavalcanti e Ed Nosal. Some Benefits of Cyclical Monetary Policy. Ensaios Econômicos da EPGE 603, EPGE-FGV, Out 2005.

[604] Pedro Cavalcanti Gomes Ferreira e Leandro Gonçalves do Nascimento. Welfare and Growth Effects of Alternative Fiscal Rules for Infrastructure Investment in Brazil. Ensaios Econômicos da EPGE 604, EPGE-FGV, Nov 2005. 
[605] João Victor Issler, Afonso Arinos de Mello Franco, e Osmani Teixeira de Carvalho Guillén. The Welfare Cost of Macroeconomic Uncertainty in the Post-War Period. Ensaios Econômicos da EPGE 605, EPGE-FGV, Dez 2005.

[606] Marcelo Côrtes Neri, Luisa Carvalhaes, e Alessandra Pieroni. Inclusão Digital e Redistribuição Privada. Ensaios Econômicos da EPGE 606, EPGE-FGV, Dez 2005.

[607] Marcelo Côrtes Neri e Rodrigo Leandro de Moura. La institucionalidad del salario mínimo en Brasil. Ensaios Econômicos da EPGE 607, EPGE-FGV, Dez 2005.

[608] Marcelo Côrtes Neri e André Luiz Medrado. Experimentando Microcrédito: Uma Análise do Impacto do CrediAMIGO sobre Acesso a Crédito. Ensaios Econômicos da EPGE 608, EPGE-FGV, Dez 2005.

[609] Samuel de Abreu Pessôa. Perspectivas de Crescimento no Longo Prazo para o Brasil: Questões em Aberto. Ensaios Econômicos da EPGE 609, EPGE-FGV, Jan 2006.

[610] Renato Galvão Flôres Junior e Masakazu Watanuki. Integration Options for Mercosul - An Investigation Using the AMIDA Model. Ensaios Econômicos da EPGE 610, EPGE-FGV, Jan 2006.

[611] Rubens Penha Cysne. Income Inequality in a Job-Search Model With Heterogeneous Discount Factors (Revised Version, Forthcoming 2006, Revista Economia). Ensaios Econômicos da EPGE 611, EPGE-FGV, Jan 2006.

[612] Rubens Penha Cysne. An Intra-Household Approach to the Welfare Costs of Inflation (Revised Version, Forthcoming 2006, Estudos Econômicos). Ensaios Econômicos da EPGE 612, EPGE-FGV, Jan 2006.

[613] Pedro Cavalcanti Gomes Ferreira e Carlos Hamilton Vasconcelos Araújo. On the Economic and Fiscal Effects of Infrastructure Investment in Brazil. Ensaios Econômicos da EPGE 613, EPGE-FGV, Mar 2006.

[614] Aloisio Pessoa de Araújo, Mario R. Páscoa, e Juan Pablo Torres-Martínez. Bubbles, Collateral and Monetary Equilibrium. Ensaios Econômicos da EPGE 614, EPGE-FGV, Abr 2006.

[615] Aloisio Pessoa de Araújo e Bruno Funchal. How much debtors' punishment?. Ensaios Econômicos da EPGE 615, EPGE-FGV, Mai 2006.

[616] Paulo Klinger Monteiro. First-Price Auction Symmetric Equilibria with a General Distribution. Ensaios Econômicos da EPGE 616, EPGE-FGV, Mai 2006.

[617] Renato Galvão Flôres Junior e Masakazu Watanuki. Is China a Northern Partner to Mercosul?. Ensaios Econômicos da EPGE 617, EPGE-FGV, Jun 2006. 